\title{
Permanent and Temporary Aspects of Urban Tourism (Case Study: George Town, Malaysia)
}

\author{
Gandhes Kusuma Gumelar \\ Department of Architecture, Tunas Pembangunan University, Surakarta, Indonesia \\ gumelargandhes@gmail.com \\ Rully \\ Department of Architecture, Tunas Pembangunan University, Surakarta, Indonesia \\ rullystmt@gmail.com
}

\begin{abstract}
As a world tourism phenomenon, cities are seen as a complex process associated with different cultures, lifestyles and a set of demands for vacations and travel. Urban tourism has unique characteristics, different from tourism in general, whose tourist attraction is intended only for those who travel. Urban tourists use urban facilities which are also used by city residents as a tourist attraction. George Town, which is located on the island of Penang, Malaysia, offers urban tourism in the form of architecture and culture of the city itself as the main attraction that is unchanged because George Town is one of UNESCO World Heritage cities that is protected by law. Urban Tourism in George Town seen from its temporary aspect is supported by various tourism events and also supporting facilities that become special interest tourism. These events, festivals and those facilities aim to enliven the town and increase the town's tourism value. Meanwhile seen from its permanent aspect, it is the city itself where the buildings are historical relics that are protected by law. So that the building will not change and its authenticity and historical value will be maintained. Iit can be seen that the permanent and temporary aspects in George Town are a dualism that is inseparable or whether the right or wrong is determined. Like any currency, they have both positive and negative sides, good and bad, depending on the case and the potential of George Town itself
\end{abstract}

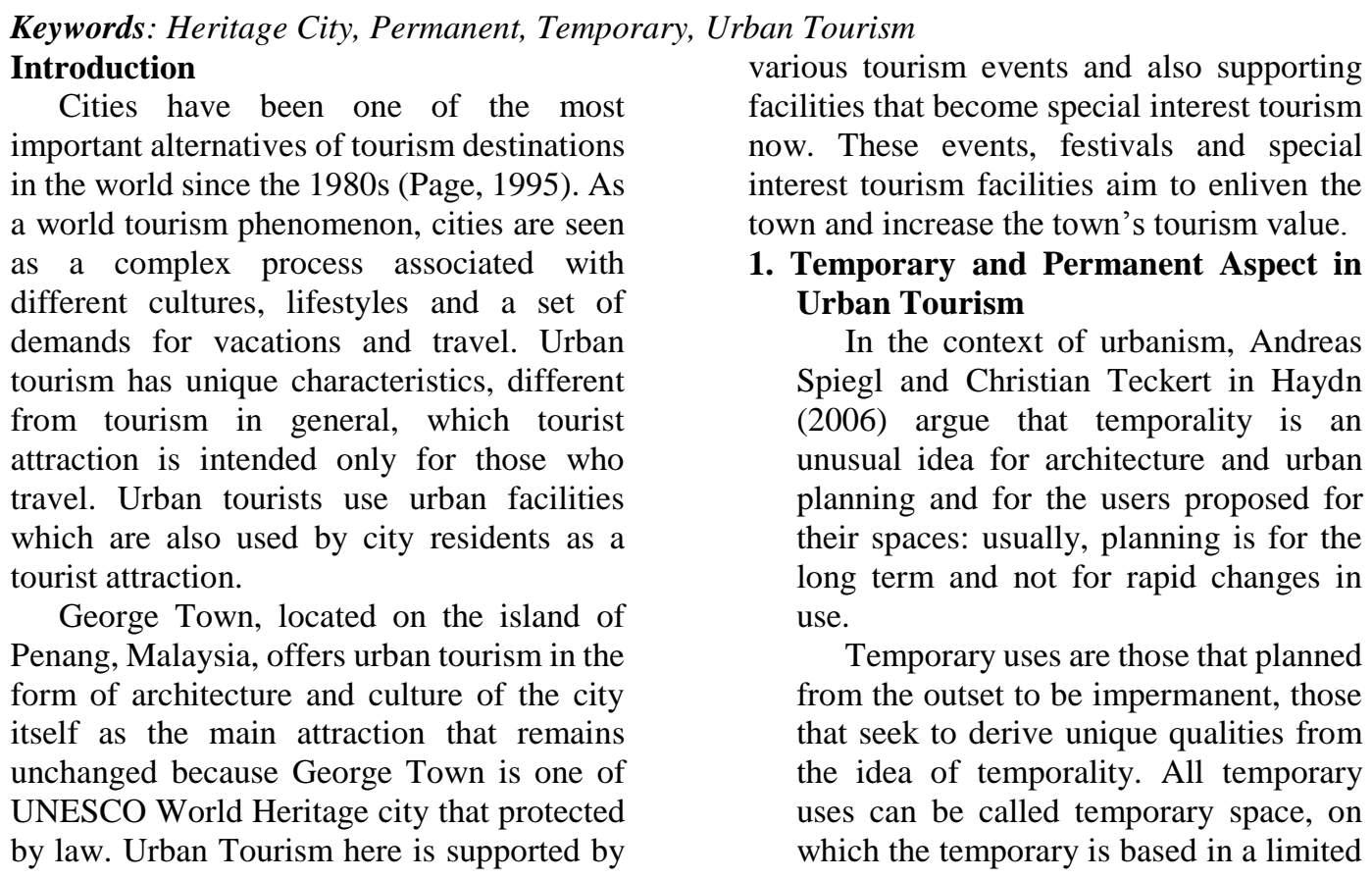


span of time, even in features of a spatial and urban quality. So it can be concluded that the temporary aspect is an urban condition that changes, is not fixed and can change places, circumstances, and forms.

Meanwhile, the permanent aspect is a condition in an urban area that is fixed, unchanged, does not change places and does not change the conditions, so that the appearance still looks original like the initial form when it was built.

$$
\text { Permanent and temporary }
$$
interventions to urban space have been developed for the conservation of urban identity and for the provision of benefit from it, including some functional and some structural decisions (Birer, 2018).

One form of temporary urbanisms are events, where events are closely related to the context of tourism. The other side of temporary urbanism is the city of events: cities are increasingly wagering on cultural policies, to improve their chances in locational competition. (Haydn, 2006)

In this case, that means cultural events as part of the historic city, which are intended to make it more interesting for tourism and brighten the city itself. This so-called creative class.

\section{George Town, Malaysia}

George Town is the largest city with an area of approximately 250 hectares as well as the capital city of the island state of Penang, Malaysia. Taken from the name of one of the British Kings, namely George III (Cipuga, 2015, http://www.cibuka.com/2015/04/georgetown-kota-bersejarah-yang.html). George Town is located in the northern-most eastern part of Penang Island. The city has a population of 510,996 inhabitants.

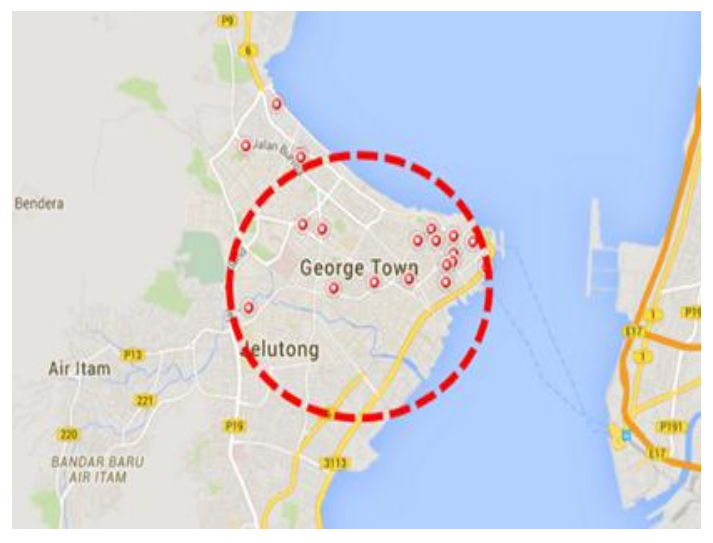

Figure 1 : George Town Location Source: Google Maps, 2020

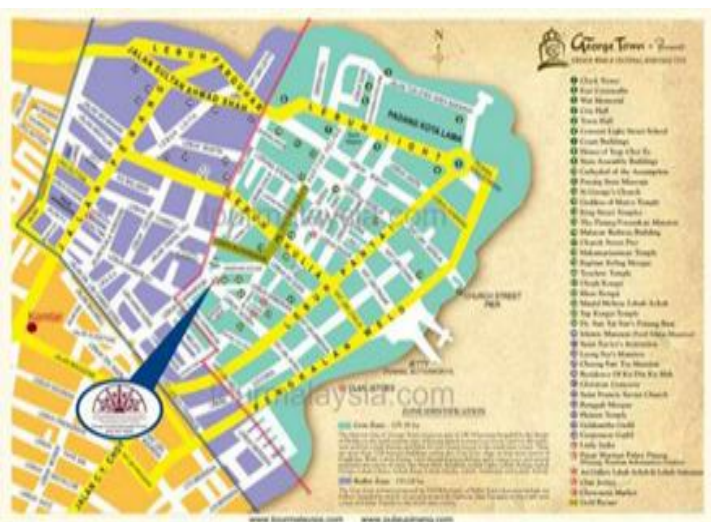

Figure 2 : George Town's Tourism Map Source: Google Images, 2020 
The rich culture and history of The rich culture and history of the city of Penang cannot be separated from the strategic location of the island of Penang in the trade route in the Malacca Strait, where Penang is a port city and the entrance to the Straits of Malacca for traders from the north

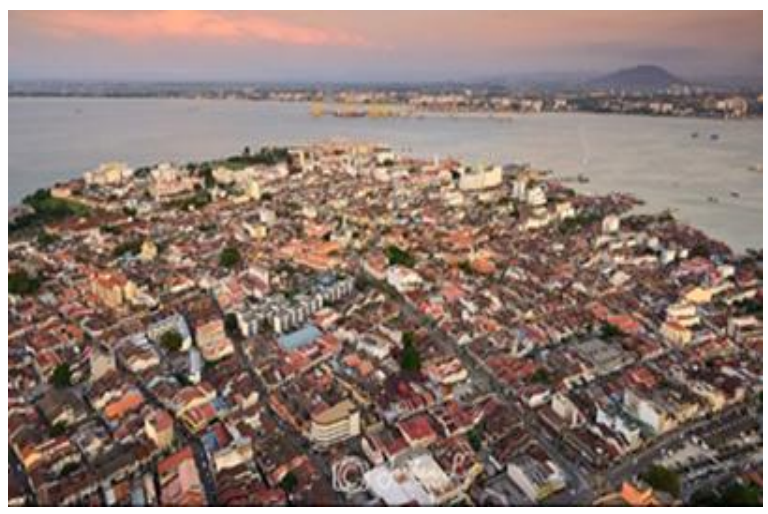

Figure 3 : George Town's View from above Source: Google Images, 2020

George Town is listed as a World Heritage City, one of the world heritage cities protected by UNESCO since July 7 , 2008. This city has many historical records that are preserved in the form of buildings with historic architecture and various relics of the British colonial era. According to the provisions of UNESCO's World Heritage Sites, the George Town area is divided into a buffer zone and a core heritage zone.

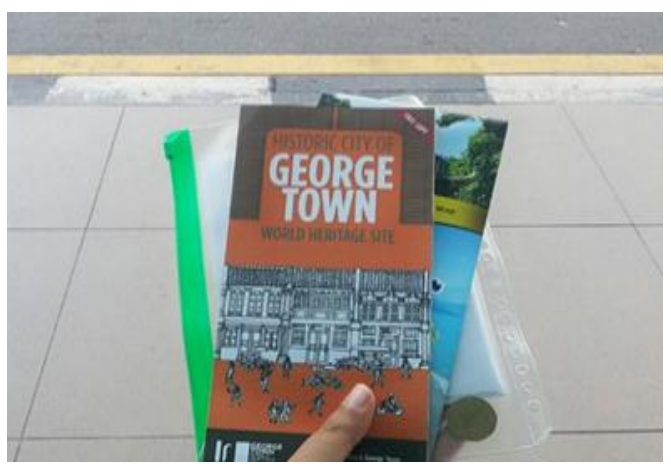

Figure 4 : George Town's Brochure as World Heritage Sites UNESCO

Source: Private doc

At first George Town was divided into six areas, which were categorized based on the density of economic and cultural activities that grew in each of these areas. However, when pursuing the restoration process, the six areas were rearranged and made into only two zones, core zone and buffer zone which surrounds the core zone
(Aini, 2009 , https://aini.rumahatiku.com/2009/05/pen ang-kota-warisan-dunia).

The core zone is 109.38 hectares and the buffer zone is 150.04 hectares. This buffer zone is outside the water/ sea area. There are approximately 4000's of old buildings from the 18 th century to the 20th century that are still preserved. 
Historically, this city was founded 200 years ago, with a collection of historical buildings depicting the ethnic diversity of Penang Island. It is recorded that ethnic Chinese, Indians, Arabs, Malays, Acheh, Siamese, Burmese and Europeans, namely the Portuguese and British have inhabited this island. So that the architectural styles in the buildings become very diverse, influenced by these ethnicities.

The type of tourism in George Town is Urban Tourism, namely tourism with an attraction in the form of a city in the form of a Heritage City itself, supported by alternative attractions which are now becoming a special interest tourism.

\section{Methods}

This research is qualitative research with a descriptive analytical method, where this research is more directed to the implementation of permanent and temporary aspects of urban tourism in George Town. Qualitative research views objects as dynamic, the result of thought construction and interpretation of the observed symptoms, and holistic because every aspect of the object has an inseparable unity. The research approach used is the rationalistic deductive paradigm, where deductive research uses theory or concept as a reference in research.

\section{Discussion}

\section{Permanent Aspect in George Town}

Historically, George Town is listed as one of the World Heritage Sites, which have been protected by UNESCO since July 7, 2008. UNESCO World Heritage Sites are places that have been nominated for an international World Heritage program managed by the UNESCO World Heritage Committee, consisting of 21 state parties. elected by the General Assembly General Assembly on a 4 year contract.
UNESCO itself defines heritage as "cultural wealth" consisting of tangible cultural treasures and intangible cultural heritage. The intangible legacy includes language, religion and traditions. Whereas tangible inheritance is the "movable" and "immovable". Immovable heritage includes historical buildings, monuments, archeological sites. Movable heritage includes paintings, sculptures, furnitures, and wall painting.

UNESCO classifies it into 4 categories, namely:

- Archaeological remains,

- Historical records and phenomena,

- Cultural remains such as language, religion and customs,

- Geology, remains paleontology and ecology.

The most prominent historical heritage or heritage in George Town can be seen from its buildings. Penang and Melaka, especially Georgetown, have the largest number of historical buildings from the colonial era in Southeast Asia. The historical building is maintained in such a way, remains standing and functions properly along with the development of life in the city.

The majority of historical buildings have European architectural styles, especially British colonials. However, apart from Europe, many of these buildings have Asian architectural styles, especially China, India and Thailand. Because geographically Penang is already close to the Malaysia-Thailand border, so there is a cultural acculturation.

In order to simplify the restoration process \& clarify the category of buildings with historical heritage, several priority criteria are made for these buildings, such as: the building must be in the core zone that is the former home of influential people in Penang in the past, and has a unique cultural architecture that is no longer found in present-day Penang buildings. 


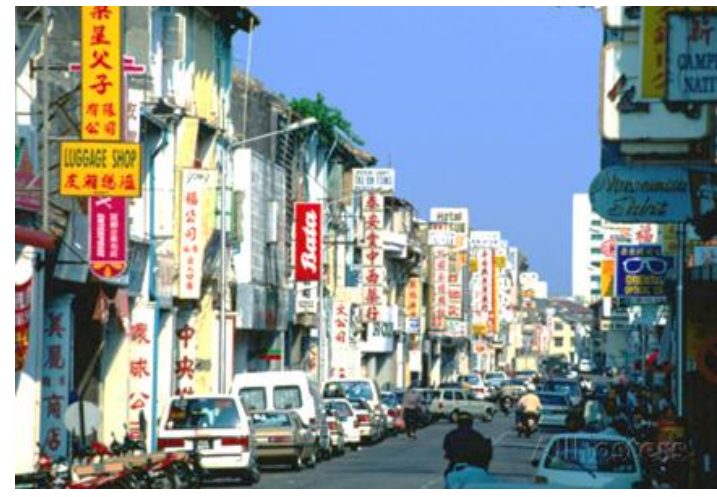

Figure 5 : Chinese Architectural Style Source: Private doc

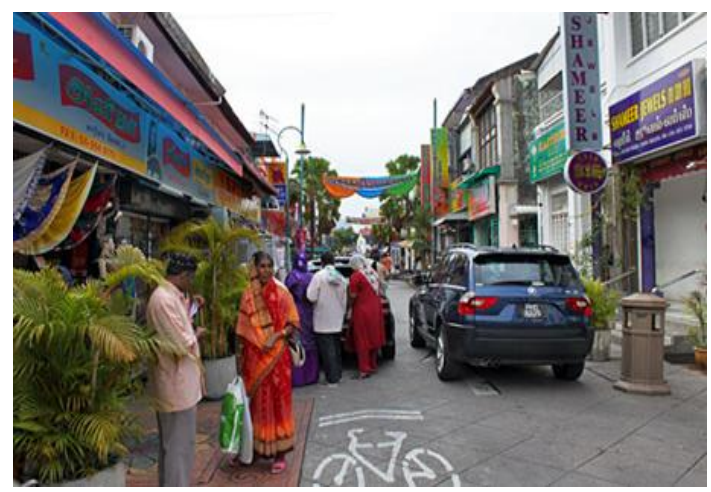

Figure 7 : Indian Ethnic Settlements Source: Private doc

Most of the buildings in George Town are an area that has not changed over time, with all its historical, cultural, and unique architectural heritage. Therefore, this city is

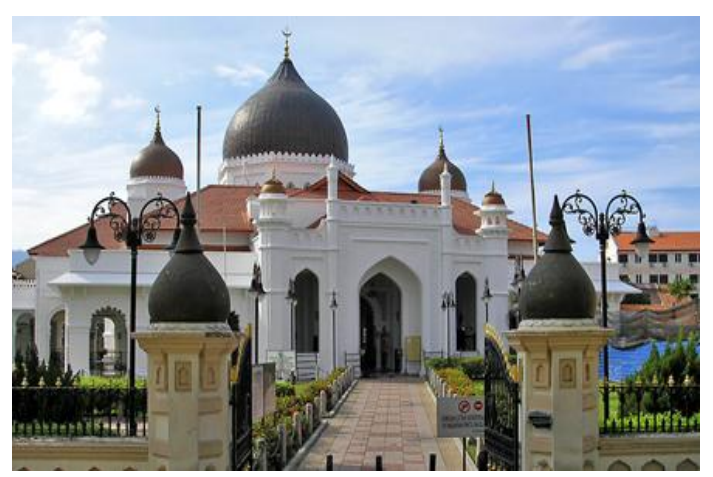

Figure 9 : Kapitan Keling Mosque Source: Google Images, 2020

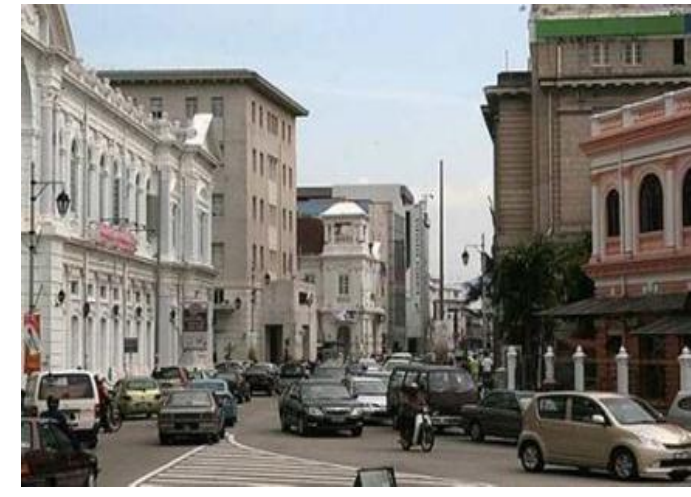

Figure 6 : European Architectural Style Source: Private doc

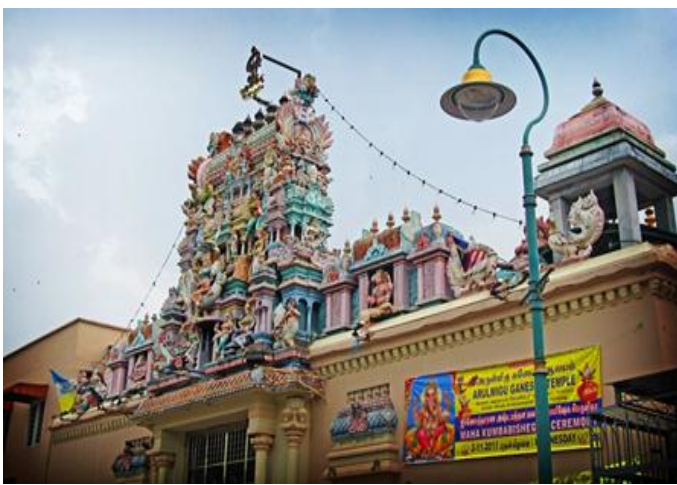

Figure 8 : Sri Mahamariamma, Indian Temple Source: Private doc

protected as a world heritage to maintain the historical value and authenticity contained in each building and its culture.

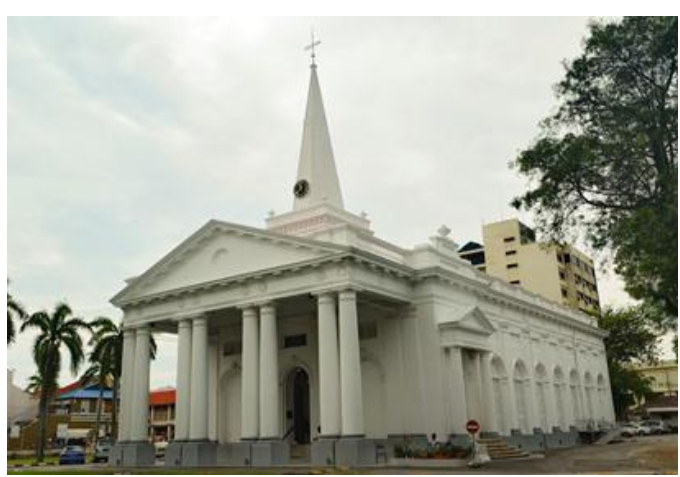

Figure 10 : St. George Church in George Town Source: Private doc 
Heritage is something that is permanent/ fixed because it is a distinctive feature which is also a historical legacy or hereditary heritage in an area that must be preserved and maintain its authenticity.

So it can be concluded that most of the buildings in George Town which are historical heritage are fixed areas, or permanent, and do not change with all the conditions and ambience that surround them.

\section{Temporary Aspect in George Town}

The number of events and festivals held in George Town is believed by the local government to increase tourist visits, both foreign and domestic. They hope that holding tourism events can improve the quality of tourists and the amount of touris's expense. In addition, with a tourism event, it can be a strategy so that tourist destinations are not only dominated by certain areas.

Allen as quoted by Teguh (2010) stated that the event is a special ritual of appointment, appearance, or celebration that is definitely planned to achieve social, cultural or common goals.

The types of events or festivals include:

a. Film Festival

It is a celebration where the contents showcase a film production

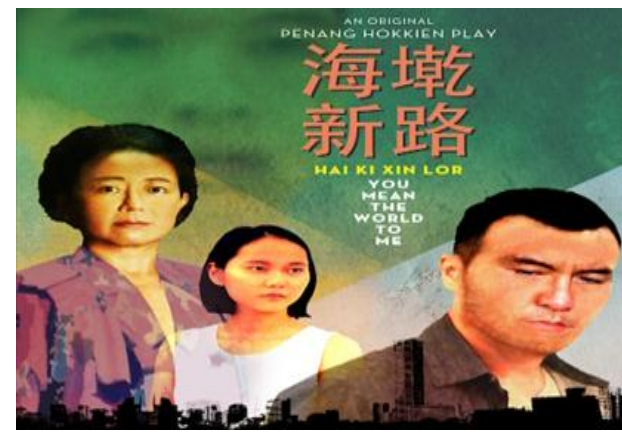

Figure 11 : Poster Hai Ki Xin Lor Movie, on George Town Movie Festival 2014 Source: Google Images, 2020

b. Music festival

Usually a series of acts in a specific place and inspired by a unifying theme, such as national music, modern music or promoting a composer's / outstanding work, can also take the form of a contest for a singer or composer.

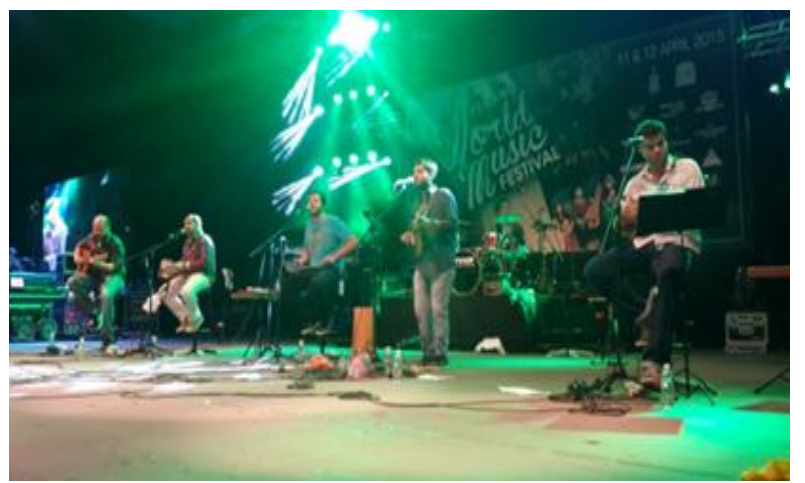

Figure 12 : Penang World Music Festival 2015 in George Town Source: Google images, 2020 
c. Art festival

It is a major event where performances, exhibitions and

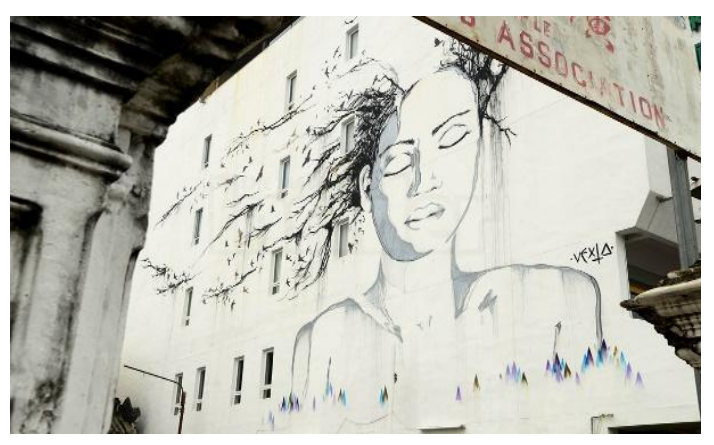

Figure 13 : Mural on Art Festival 2014 in George Town

Source: Google Images, 2020

d. Cultural festival

Cultural festivals are expressions

of views on cultural, social and

political issues.

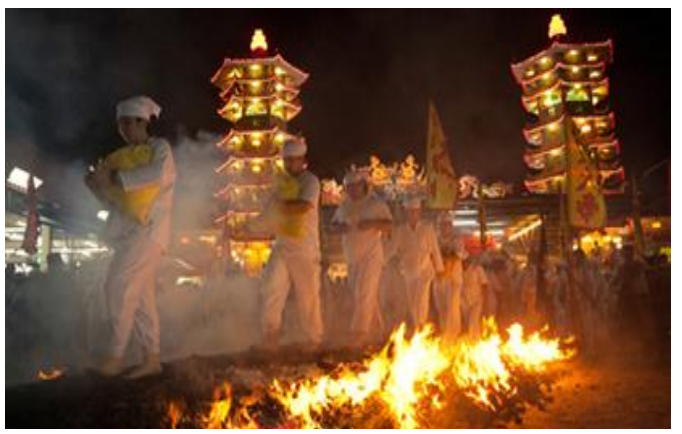

Figure 14 : Nine Emperor Gods Festival 2015, one of Cultural Event in George Town Source: Google Images. 2020

e. Sports Festival

Cultural festivals are festivals with sports as the main activity.

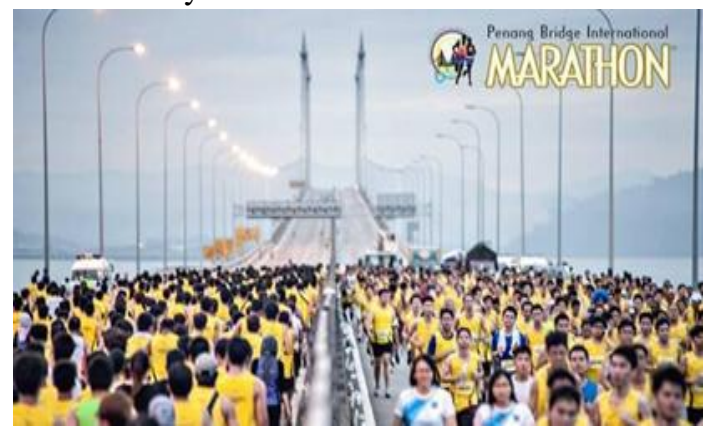

Figure 15 : Penang Bridge International Marathon in George Town Source: Google images, 2020

Faculty of Engineering Tunas Pembangunan Surakarta University 
Apart from events and festivals, special interest tourism also supports tourism in George Town which is temporary in nature.

According to Kruja and Gjyrezi (2011), urban tourism has developed, giving birth to special interest tours. Special interest tourism is driven by the desire of tourists who want a specific activity or purpose.

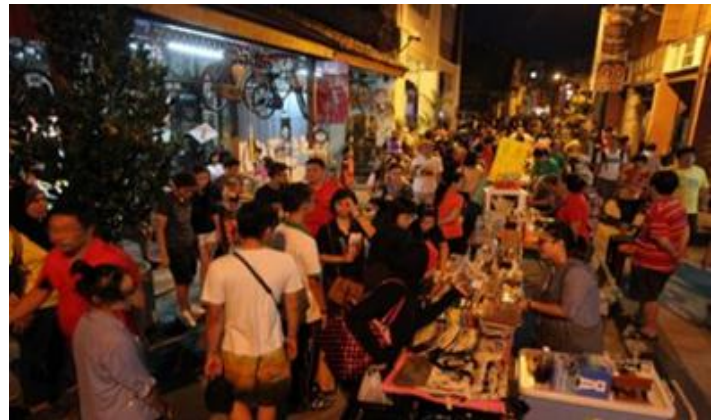

Figure 16 : Night Culinary Street Food Source: Google Images, 2020
Public facilities that were previously provided to support urban tourism are now a special attraction for tourists. Examples are night culinary tours, mural exploration, and unique transportation such as umbrella bikes in George Town.

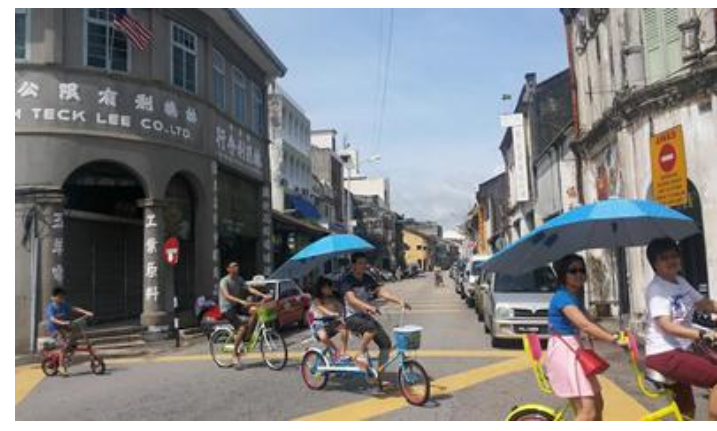

Figure 18 : One of Unique Transportation Source: Private Doc

Both events or special interest tourism in George Town are held for a certain period of time. With the existence of events and special interest tourism, tourism in George Town is increasing because these things always change according to community demand from time to time as the area in George Town becomes more and more alive.

So it can be concluded that events and festivals, as well as special interest tourism here are temporary areas where they are temporary, changing according to trends and community dynamics.

\section{Conclusion}

The permanent aspect of George Town is the city itself where the buildings are historical relics that are protected by law. So that the building will not change and its authenticity and historical value will be maintained.

However, the ever-changing trends and dynamics of society make market demand change as well. So it is necessary to raise a temporary realm that can accommodate and realize this request. The temporary domain in George Town is a temporary event / festival as well as special interest tours, and only exists for a certain period of time. 
Events and special interest tours that were originally used to accommodate people's requests for heritage areas can cause historical values in the area to be threatened. Examples include the vandalism, vandalism, riots, and overlapping interests of various parties that occurred along with the increase in tourism and tourist visits in George Town.

From the explanation above, it can be seen that the permanent and temporary aspects in George Town are a dualism that is inseparable or whether the right or wrong is determined. Like any currency, they have both positive and negative sides, good and bad, depending on the case and the potential of George Town itself. This is also influenced by the strategy and participation of the government, managers, related agencies, and the community to increase the positive side and minimize the negative side in the permanent and temporary realm in George Town.

\section{References}

\section{Books:}

Haydn, Florian, Temporary Urban Spaces: Concepts for the Use of City Spaces, Birkhauser, Berlin, 2006;

Madanipour, Ali, Cities in Time Temporary Urbanism and the Future of the City, Bloomsbury Academy, New York, 2017; Sugiyono, Metode Penelitian Kuantitatif Kualitatif dan $R \& D$, Bandung: Alfabeta, 2014;

Page, Stephen, Urban Tourism, Routledge, London, 1995.

\author{
Articles Published in Conference \\ Proceedings \\ Birer, Emel, "Sustainable Interventions In \\ The Urban Space: Temporary And \\ Permanent Additions" Conference Paper \\ on SPACE International Conference \\ 2018 Sustainable Architecture, Planning \\ and Urban Design, April 2018.
}

Journals Articles:

H. Rachmad, Teguh, "Strategi Public Relations dalam Meningkatkan Citra Perguruan Tinggi Swasta di Jawa Timur (Studi Kasus Perguruan Tinggi Swasta di Universitas Pembangunan Nasional Veteran Jawa Timur)," Jurnal Komunikasi, Vol. 9 (1), Maret 2015: 2140;

Kruja, Drita, Albana Gjyrezi, “The Special Interest Tourism Development and the Small Regions," Turizam Journal, Vol 15 (2), 2011:77-89.

Website:

Aini.rumahhatiku.com, "Penang: Kota Warisan Dunia," https://aini.rumahatiku.com/2009/05/penan g-kota-warisan-dunia/, accessed on Sunday, November 8 2020;

Chairunisa, Mentari, Kompas.com, "Berlibur ke Penang? Ini Dia Festival yang Wajib Dikunjungi,"http://travel.kompas.com/read/ 2015/08/23/140600127/Berlibur.ke.Penang .Ini.Dia.Festival.yang.Wajib.Dikunjungi, accessed on Sunday, November 8 2020;

Cipuga, Aneuk, Destinasi Percutian, "George Town: Kota Bersejarah yang Memukau Mata," http://www.cibuka.com/2015/04/georgetown-kota-bersejarah-yang.html, accessed on Monday, November 92020. 